\title{
The Shanghai Modern Woman's American Dreams: Imagining America's Depravity to Produce China's “Moderate Modernity”
}

\section{LOUISE EDWARDS}

The author teaches at Hong Kong University.

This article explores images of the United States featured in the 1930s Shanghai women's magazine Linglong. This imagined America reflected a reorientation in ideas about how to be simultaneously modern and Chinese. The United States became a symbolic location for Linglong's readers as they grappled with personal concerns in their negotiations with families and communities about appropriate feminine behavior for Chinese women seeking to be modern and cosmopolitan. These readers found in the depiction of American life answers to their anxieties about appropriate limits for their modern city lifestyle. The imagined America provided convenient boundaries for readers and editors alike. Linglong presented a vision of unbridled, limit-free American lifestyles as "the extreme," allowing China's modern women to plot their behavior along an imagined continuum stretching between American depravity and the prison of Confucian morality.

Key words: Chinese women, American women, modernity, Linglong magazine, urban lifestyles, images of femininity, fashion

This article explores the way in which images of the United States featured in the 1930s Shanghai women's magazine Linglong and argues that the imagined America reflected a significant point of reorientation in ideas about how to be simultaneously modern and Chinese. The United States became an important symbolic location for readers of the magazine as they grappled with their own pressing personal concerns in negotiations with families and communities about appropriate feminine

This research was made possible through a grant from the University Grants Council of Hong Kong's General Research Fund. All Chinese names referred to in the article follow Chinese order (i.e., family name followed by personal name) unless the original work was published in English with names in the reverse order. All translations of Chinese-language material are my own unless otherwise stated.

Pacific Historical Review, Vol. 81, No. 4, pages 567-601. ISSN 0030-8684

(C) 2012 by the Regents of the University of California. All rights reserved.

Please direct all requests for permission to photocopy or reproduce article content through the University of California Press's Rights and Permissions website, at http://www.ucpressjournals. com/reprintinfo.asp DOI: phr.2012.81.4.567. 
behavior for Chinese women seeking to be modern and cosmopolitan. Readers of the magazine found in the depiction of life in the United States answers to their anxieties about "How much dancing is too much dancing?" and "What are the limits to a decent young woman's socializing in public?" In this period of rapid social and cultural change, Linglong's editors clearly believed that women wanted guidance about appropriate behavioral limits for their modern city lifestyle in vibrant, cosmopolitan Shanghai. With the boundaries for behavior from their mothers' and grandmothers' days no longer relevant, "What was a young woman to do?" 1 The imagined America provided convenient boundaries for readers and editors alike.

Linglong presented a vision of unbridled, limit-free American lifestyles as "the extreme." China's modern women could plot their behavior along an imagined continuum stretching between American depravity (glamorous and oh-so-romantic) and the dull prison of Confucian morality, complete with its idealized segregation of "good" women from public space altogether. ${ }^{2}$ On such a continuum, a "moderate" amount of dancing and socializing with men was readily quantified and only reasonable, surely! Within this schema, Linglong's readers could think of themselves as "good Chinese women" while still having a bit of fun in the nightclubs and coffee shops that filled bustling pre-war Shanghai. After all, consider the behavior of the depraved Americans!

Linglong magazine appeared on the newsstands of China's major cities every Wednesday between 1931 and 1937; it retailed for seven fen in Shanghai and a little more in other urban centers. Yunxiang Gao tells us that this was "inexpensive," and the magazine's content indicates that its target audience stretched from factory workers to professionals. ${ }^{3}$ A leading author of the period,

1. Gary Wang noted this point in his statement that "much of Linglong's content set out to reform how men and women socialize in the xin shehui [new society]." Gary Wang, "Making 'Opposite-sex Love' in Print: Discourse and Discord in Linglong Women’s Magazine, 1931-1937," Nan nü: Men, women and gender in China, 13 (2011), 247.

2. The reverse phenomenon-American romanticization of China-is explored in John Haddad, The Romance of China: Excursion to China in U.S. Culture, 1776-1876 (New York, 2008), which explained that dreams of China performed a wide array of desires for Americans in their nation-building between the 1770s and 1870s.

3. Yunxiang Gao, "Nationalist and Feminist Discourses on Jianmei (Robust Beauty) during China's 'National Crisis' in the 1930s," Gender and History, 18 (2006), 550. 
Eileen Chang, wrote, "every female student had an issue of Linglong magazine in hand during the 1930s." Its stated goal was "to promote an exquisite life for women, and promote noble entertainment in society" (zengiin "funü" youmei shenghuo; tichang shehui gaoshang "yule"). ${ }^{5}$ Linglong was an explicitly commercial publication designed to engage and entertain, and it stood distinct from the myriad feminist associations that published journals with heavy political content during this decade. According to Carol Chin, Chinese feminists also made comparisons with the United States "in their quest for their own modernity." ${ }^{6}$ For Linglong, with its goal of promoting "noble" entertainment in China, American excess became a useful counterpoint.

Recent scholarship on Linglong has alerted us to its many internal ideological contradictions. Gary Wang described the magazine's content as a tension between "cutting edge and playful iconoclasm and ... conformism and token gestures to avoid explicit transgressions of mainstream respectability." Yunxiang Gao and Hsiao-pei Yen have shown how the magazine co-opted and challenged moralizing government campaigns aimed at enhancing physical health among women by promoting the allure of fashionable "healthy beauty." 8 Barbara Mittler alerted us to the magazine's polyphony in its "ambiguous descriptions of male and female behavior" and argued that in this ambiguity the magazine

4. Eileen Chang, "Talking About Women" [Tan nüren], translation from "The Magazine," online at http://www.columbia.edu/cu/lweb/digital/collections/linglong/ about.html, accessed June 16, 2012. The original version appeared in Tiandi [Heaven and Earth], 6 (March 1944). Columbia University's C. V. Starr East Asian Library has digitized Linglong and made it publicly and freely available online at the website above. The translation of Chang is from Columbia University's website.

5. "Ben zazhi de mubiao" [The goals for this magazine], Linglong, 1 (1931), 13; emphasis in original.

6. For a discussion of the ways that China's feminists viewed western feminism, see Carol C. Chin, "Translating the New Woman: Chinese Feminists View the West, 1905-15," Gender and History, 18 (2006), 490-518. She argued that, "Although Chinese feminists looked to American women for inspiration, they were not attempting to translate American culture into the Chinese context, nor were they merely imitating the foreign models. Rather they were engaged in appropriating images of American women in their quest for their own modernity." Ibid., 497.

7. Wang, "Making 'Opposite-sex Love' in Print," 275.

8. Gao, "Nationalist and Feminist Discourses on Jianmei," 548. Hsiao-Pei Yen, "Body Politics, Modernity and National Salvation," Asian Studies Review, 29 (2005), 168. 
produced a new, distinct form of gentility. ${ }^{9}$ I extend their findings to show how these contradictions are the very essence of a process of testing social boundaries about appropriate behavior. When situated in a framework of international comparison, this process produced a new moral spatiality-moderate Chinese modernity.

While addressing readers' pressing personal concerns about negotiating life in the big, modern city, at a deeper level, the magazine's content reflected a trend typical of the 1930s in which Chinese urbanites and political leaders were actively creating a place for China and Chinese culture in a modern, cosmopolitan world. Producers of cultural products and political structures sought to be both modern and Chinese. This desire to find a uniquely Chinese path to modernity was clearly manifest in the 1930s and stood in striking contrast to the calls for unrestrained westernization that dominated the New Culture Movement (1915-1925). The fluctuations in popular Chinese imaginings of the United States in the first four decades of the twentieth century provide a classic example of the contradictory and evolving operation of Occidentalism. The Occidentalism of the New Culture Movement manifested itself in reformers' enthusiasm for the teachings of the western "Mr. Science and Mr. Democracy" and in their iconoclastic demolition of Confucianism as a moral, political, and cultural force. By the 1930s ordinary people had a renewed pride in China-in part spurred by the Nationalist government's vision for a modern Chinese culture and nation made possible by their successful reunification of the country under one government in 1928.

Members of the Nationalist Government, in Susan Glosser's words, had a clear desire "for the modernization of China's customs in order to bring them into line with those of the international community." 10 In regard to the status of women, they implemented radical reforms of family, marriage, and inheritance laws that confirmed women's legal independence from men, be they fathers, brothers, or sons. ${ }^{11}$ More generally, they planned for the

9. Barbara Mittler, "In spite of gentility: women and men in Linglong (Elegance), a 1930s women's magazine," in Daria Berg and Chloe Starr, eds., The Quest for Gentility in China: Negotiations Beyond Gender and Class (London, 2007), 211.

10. Susan L. Glosser, Chinese Visions of Family and State, 1915-1953 (Berkeley, 2003), 82.

11. See Margaret Kuo, "The Legislative Process in Republican China: The 1930 Nationalist Family Law and the Controversy over Surnames for Married Women," Twentieth-Century China, 36, no. 1 (2011), 44-66. 
emergence of a new economic system that privileged industrialization and would stand to defend China against internal disruption and external invasion. ${ }^{12}$ They rolled out European and American-style scientific hospital and education systems. ${ }^{13}$ Even in the political realm, the pressure to appear modern to an external eye was manifest in various laws that adopted the international benchmark of political equality for all adult citizens. ${ }^{14}$ Nevertheless, in the Nationalist Government period, attention to the international norms of powerful nations no longer meant a wholesale rejection of China's potential for its own distinctive version of modernity. ${ }^{15}$

R. David Arkush and Leo Lee described this shift over the first decades of the century in their study of Chinese impressions of America by encapsulating the period from the 1900s through to the end of the 1920s with the term "Model America" and that of the 1930s and 1940s as "Flawed America." They explained the shift this way: "By the 1930s and 1940s, America was becoming increasingly familiar to literate and urban Chinese," but "with familiarity and deeper understanding came a somewhat sharper awareness of less attractive aspects of American society."16 I build upon their explanation by arguing that images of the United States took on a different hue in the 1930s because Chinese readers and leaders needed to envisage a different type of America in order to forge a new type of China. In other words, to be useful to China's leaders and reformers in the 1930s, the idea of America had to change from a model of modernity to a model of excess within which China could be posited as modern and moderate. In this new political context,

12. See Margherita Zanasi, Saving the Nation: Economic Modernity in Republican China (Chicago, 2006), 4.

13. See Tina Johnson, Childbirth in Republican China: Delivering Modernity (Lanham, Md., 2011), and Helen M. Schneider, Keeping the Nation's House: Domestic Management and the Making of Modern China (Vancouver, B.C., 2011).

14. See Louise Edwards, Gender, Politics and Democracy: Women's Suffrage in China (Stanford, Calif., 2008).

15. In 1932 Linglong made a call for the "entertainment-ization of science" on the basis that the then current trend to promote scientific thinking in order to achieve a modern, strong China would be advanced remarkably if it united with the entertainment sphere. Readers were reminded of the rapid spread of radio, thanks to people's desire for entertainment. "Kexue yu yule" [Science and entertainment], Linglong, 58 (1932), 382.

16. R. David Arkush and Leo O. Lee, eds., Land Without Ghosts: Chinese Impressions of America from the Mid-Nineteenth Century to the Present (Berkeley, 1989), 143, 144. 
the United States shifted from the progressive "Occidental model other," worthy of wholesale emulation, to become a marker of "progress too far"-an extreme that would not suit China. And, under the new regime, it was on women's bodies that the parameters of modern China would be forged.

Women and women's bodies were central to the creation of a modern China. Leo Lee has pointed out that at this time "the display of the female body [in China] had become part of a new public discourse related to modernity in everyday life." ${ }^{\prime 17}$ Barbara Mittler explained that "modernity . . . became a spiritual adventure for China, [and] woman became its most powerful symbol."18 Katrina Gulliver's exploration of Shanghai's modernity similarly summarized the central symbolic role of women in creating Chinese modernity as one of aspiration: "The Modern Woman was a Western concept to which other countries could aspire." ${ }^{19}$ But this "catching up" was not a values-free process. Influential educator Sophia Chen Zen spoke of the broad public anxiety that the processes of westernization were "too much, too soon." ${ }^{20}$ The key problems on the ground for real women, then, became questions of degree: How much was too much, and how fast was too fast? More specifically, how much of a Chinese woman's body was viewed, in what position was that body placed, and in whose company did she share public space? "Chinese moderation," as marked against an American extreme, helped establish those parameters and create a new vision of a modern China.

Such international comparisons were fundamental to the notion of modernity circulating in China at this time. Modernity was more than a linear trajectory from the traditional past to the

17. Leo Ou-fan Lee, Shanghai Modern: The Flowering of a New Urban Culture in China, 1930-1945 (Cambridge, Mass., 1999), 74. Charlotte Weber has shown that Middle Eastern women also used a comparison with "the imagined west" to chart new space for their movement. See Charlotte Weber, "Between Nationalism and Feminism: The Eastern Women's Congresses of 1930 and 1932," Journal of Middle East Women's Studies, 4, no. 1 (2008), 83-106.

18. Barbara Mittler, "Defy(N)ing Modernity: Women in Shanghai's Early NewsMedia (1872-1915), Jindai Zhongguo funü shi yanjiu [Research on the history of women in modern China], 11 (2003), 217.

19. Katrina Gulliver, "Shanghai's Modernity in the Western Eye," East-West Connections, 9 (2009), 131.

20. Katrina Gulliver, "Sophia Chen Zen and Westernized Chinese Feminism," Journal of Chinese Overseas, 4 (2008), 266. 
dynamic future. ${ }^{21}$ Modernity was also a spatial matrix in which China, as a geographic and cultural location, was perceived as competing with other geographic and cultural locations to achieve modernity. Moreover, this global competition involved speed, not just skill, fashion, or technology. A country that sought modernity experienced this aspiration within a sense of a rapidly moving present. The urgency inherent in ideas about modernity in the first half of the twentieth century was at once cosmopolitan, a test of speed, and a progression along a historical trajectory away from the past. ${ }^{22}$ Moreover, China's new leaders of the 1930s sought to create a distinctly Chinese modern destiny, marked by its political and social moderation (albeit conveniently undefined), and Linglong would thus help Shanghai's readers know how much was too much and how fast was too fast. Gary Wang has argued that Linglong "attempted to offset [its] patent commercialism by subscribing to the "moral economy" that was a crucial part of the publishing scene in China at this time..$^{23}$

At the level of popular culture, evidence of China's selfdetermined modern moderation manifested itself by presenting the United States as the land of the too-free and the home of the depraved. The dominance of American stories in Linglong can be explained in part by the global impact of Hollywood movies at this time. The imaginary world into which Chinese movie-goers escaped when they went to the cinema was an American spatial

21. The international car races that commenced in the first years of the twentieth century are literal examples of the importance of speed and the importance of international comparison to the popular conception of modernity: for example, the 1907 Peking to Paris automobile race sponsored by Le Matin, the 1908 New York to Paris race co-sponsored by Le Matin and the New York Times, and the 1909 Transcontinental Auto Contest held as part of the trans-American Atlantic-to-Pacific race staged as part of the Alaska-Yukon-Pacific World's Fair. Terrence M. Cole explained the significance of speed to popular conceptions of these races, in Terrence M. Cole, "Ocean to Ocean by Model T: Henry Ford and the 1909 Transcontinental Auto Contest," Journal of Sport History, 18 (1991), 224-240. Airplane races served the same purpose of linking speed and distance to modernity with races across continents and oceans.

22. Modernity had been a contested concept in China during the decades prior to the 1930s. Barbara Mittler explained that the "new" had been "discredited for millennia" in China and despised for its "negation of venerated classic ideas, passed down from the great sages." Mittler, "Defy(N)ing Modernity," 217.

23. See Gary Wang for a discussion of the careful manner that Linglong's editors reassured readers of the profound sincerity and high moral ideals that underpinned the magazine. Wang, "Making 'Opposite-sex Love' in Print," 257-258. Direct quote found on pp. 258-259. 
and cultural realm. The cultural power of England and Europe in Shanghai was not evident in Linglong, targeting, as it did, aspirants to the fashionable, modern lives depicted in the cinemas. Hollywood stories provided ample evidence of American excess as readers thrilled at frank discussions of divorce, open depictions of sexual desire, and abundant images of languid flesh extruding from long, glamorous dresses. Stories of stars and films from Hollywood dominated the entertainment section of every issue. Linglong supplemented these reports of Hollywood with ample articles of ordinary American excess. Hollywood stars thus provided the glamorous images for the more generalized story of the immoderate American society. While stories from other nations, particularly those in Europe, were also featured, the United States loomed largest among the comparator nations for China, reflecting the rising influence of America in the world at this time.

The magazine's position was clear-America was indisputably modern, but it was devoid of morality. For itself, China would take another path. China would aim to avoid the situation George Kao encountered in New York in 1937. He described to Chinese readers the then-new New York phenomenon of the "striptease" with a moral calibrator typical of this time:

It is a woman standing on a stage in front of an audience taking her clothes off piece by piece to the point considered by police regulations to be an offense against morals-except that, frankly, the morals in New York and most other American cities have already been damaged to the point that nothing more can be done to them $!^{24}$

Clearly, this vision of life in American cities was incomplete. Sophia Chen Zen warned North Americans of the erroneous impressions that many Chinese had of the United States from the export of America's popular culture. A newspaper report of a lecture held in Winnipeg quoted her as saying,

American moving pictures are doing harm in China, socially, for they draw a distorted picture of American life, and as social life in China is something new for which the older generations have no example,

24. George Kao (Gao Keyi, Qiaozhi Gao), "Burlesque," in Arkush and Lee, eds., Land Without Ghosts, 166. 
the young people take their models from the actors they see depicted in the screen. ${ }^{25}$

But this "distorted" view met a distinct demand in China-people there needed and wanted to imagine a place of excess in order to create their own modern Chinese virtue. In Linglong's cartography of excess, "traditional China" stood at the other pole-replete with excessive restrictions on women's behavior. Mittler's work on the journal explains how it pitched "traditional Chinese morals" against Linglong's own "modern morals." ${ }^{26}$ If we extend this comparison to include spatial terms, we can see the importance of the United States as a geographic moral pole as well. By establishing dramatic and sometimes highly exaggerated temporal and spatial extremes, the very radical nature of the shifts that Linglong's modern women themselves were making would be protected from direct censorial gaze.

\section{Linglong's evolution}

Linglong's Shanghai publishers, the Sanhe Company of Nanjing Road, targeted the "Modern Women" sophisticates of Shanghai as well as a broad mass reading audience who had emerged from the schools of urban China during the 1920s. This readership sought to reaffirm its modern credentials and, thanks in equal measure to the daily presence of foreign concessions in Shanghai and to rising Chinese nationalism, knew it was Chinese. The potential readers were moderately educated women with disposable income and grand dreams of beauty, fame, and a life of ease. Students in Shanghai's many women's colleges and the expanding numbers of white-collar workers in city offices appear to have been its main audience, apart from young ladies of leisure supported by family wealth. ${ }^{27}$ Linglong was not a journal devoted to rousing women into action on behalf of any particular political party, nor even on behalf of their sisters in rural China. It frequently expressed sentiments of national pride or indignation at

25. Sophia Chen Zen, in Winnipeg Free Press, Oct. 4, 1933, cited in Gulliver, "Sophia Chen Zen and Westernized Chinese Feminism," 266.

26. Mittler, "In spite of gentility," 211.

27. For an in-depth discussion of publishing in Shanghai at this time, see Christopher Reed, Gutenberg in Shanghai: Chinese Print Capitalism (1876-1937) (Vancouver, B.C., 2004). 
perceived or actual slights against "China," but it avoided explicit calls to political action.

Funding for the publication came from Mr. Lin Zecang, a businessman heading the Sanhe group. Linglong regularly advertised the Sanhe group's other business angles, including its Canindrome and beauty products. It was a pocket-sized thirteen centimeters (five inches) in height, and issues ranged between thirty and eighty pages in length. The magazine could be read from both directions-the front-to-back section included articles on women's matters ("How to stop your husband from straying?"), and the back-to-front section focused on cinema, music, and celebrity ("After Janet Gaynor's divorce"; music scores for Irving Berlin's latest songs). It was lavishly illustrated with photos or line drawings accompanying each article.

Linglong was an explicitly commercial operation. In this regard, it contrasted with many contemporaneous journals targeting women readers that derived from political activism-for example, Women's Life (Funü shenghuo), which emerged in Shanghai in 1935 and presented readers with debates on political affairs. Edited by feminist Shen Zijiu (1898-1989), the latter journal included no discussion of Hollywood stars or the latest movies. Neither did it provide advice on dating, whether Chinese-style or American-style. Instead, international comparisons were drawn from articles written by overseas women activists reporting on their own national political struggles. After the invasion of Shanghai in 1937, Women's Life moved to the war-time capital, Chongqing, and continued to publish into 1940. Its explicit intention was to mobilize women to take an active role in advancing their own status and in resisting Japan.

In contrast to the public political profile of Shen Zijiu, the members of Linglong's editorial board remain largely unknown figures. Board members Ms. Chen Zhenling, Mr. Zhou Shexun, and Mr. Lin Zemin featured prominently through the magazine as authors of multiple articles. Gary Wang has argued that Chen was a pseudonym for a group of authors. ${ }^{28}$ It was not unusual for men to work in all capacities on women's magazines during this time. Many magazines targeting women readers, both commercial and political, had men in their editorial teams, and some of them were

28. "The Magazine," online; Wang, "Making 'Opposite-sex Love' in Print," 246. 
prominent women's rights advocates. ${ }^{29}$ Many of Linglong's contributors came from outside the editorial group and consisted largely of women readers whose articles were actively solicited. Some of these contributors asserted their educational status (for example, "University Student" or "Latin Dance Teacher") to mark their authority and fashionability.

The increasing aggression of Japan signaled the end of the magazine's existence. War was declared on July 7, 1937, and Shanghai experienced direct military attacks from August 13, 1937, through to the retreat of Chinese troops at the end of November that same year. The magazine's last issue was published on August 11, 1937, only two days before Japanese troops invaded Shanghai. That issue's lack of a "final closing notice" alerting its readers to the magazine's closure suggests that it was a sudden decision induced by the trauma of war.

Over the course of its life, the magazine probably evolved in response to political rather than economic pressures. In February 1934 Chiang Kai-shek and Soong Mei-ling launched the New Life Movement, a campaign aimed at improving the morals of the country and reversing its putative spiritual degeneration. Although it has often been described as a conservative movement, Arif Dirlik has demonstrated that, in its conception, the movement was "not a traditional but a modern response to a modern problem." Yet, on the ground, the call to prevent moral degeneration gave credence to conservative forces seeking to rein in the Modern Women in whose company Linglong's readers would have considered themselves to belong. ${ }^{30}$ Probably in response to the New Life Movement, the journal adopted a far more conservative style from 1934, but this conservative trend also indicated the increasing application

29. See, for example, Zhang Xichen's (1889-1969) editorship of the longestrunning women's magazine Funü zazhi [The Ladies' Journal], founded in 1915, and his role in publishing Xin nüxing [New Femininity] in 1926.

30. Arif Dirlik, "The Ideological Foundations of the New Life Movement: A Study in Counterrevolution," Journal of Asian Studies, 34 (1975), 945. For a deeper explanation of the New Life Movement's impact upon women, see Yen, "Body Politics, Modernity and National Salvation," 170-181. Elsewhere, I have shown that the Modern Woman faced criticism not only from conservatives. Women radical activists also bemoaned the fact that the Modern Woman risked losing her political edge as she became associated with a fashionable urban lifestyle rather than political campaigns to "save the nation" or "advance women's rights." See Louise Edwards, "Policing the Modern Woman," Modern China, 26 (2000), 115-147. 
of Nationalist Government censorship rulings in Shanghai. ${ }^{31}$ Parks Coble argued that, although the Nationalist Government had press censorship laws in place from 1930, the laws were effectively enforced only from 1934 "when the government established the Shanghai Censorship Commission directly under the Publicity Department of the Guomindang [Nationalists]."32

The increasing conservatism of the magazine in 1934 is clear from a simple survey of the illustrations published over the course of its life. The photos of nude women that featured in the first three years were absent in later years. ${ }^{33}$ As the nudes disappeared, pictures of children and babies appeared in increasing numbers, alongside portraits of wholesome young women in parkland settings.

31. This current article focuses primarily on the years 1931-1934 because the censorship after 1934 complicates the commercial "purity" of the comparatively free years when publishers and editors were better able to present readers with content they imagined would be attractive to readers. For a discussion of the commercial impact of the Modern Woman in China, see Tani E. Barlow, "Buying In: Advertising and the Sexy Modern Girl Icon in Shanghai in the 1920s and 1930s," in Alys Eve Weinbaum, Lynn M. Thomas, Priti Ramamurthy, Uta G. Poiger, Madeleine Yue Dong and Tani E. Barlow, eds., The Modern Girl Around the World: Consumption, Modernity, and Globalization (Durham, N.C., 2008), 288-316.

32. Parks Coble, "The Anti-Japanese Movement in China: Zou Tao-fen and the National Salvation Association, 1931-1937," Journal of Asian Studies, 44 (1985), 296.

33. Nudity was primarily associated with Europeans, in particular with Germans, rather than Americans. German women were frequently depicted as going about their daily business in the nude. French nudes appeared as artistic objects of the human form. Neither style was particularly "sexy" - the clothed American woman occupied this sexualized position through the sensual manner in which her clothing was worn. The completely naked Germans and French women were presented as curiosities of the Naturalist Movement. See the pictures of nude French models in Linglong, 42 (1932), 1674, and of German women sunning themselves naked in ibid., 53 (1932), 120. One photo included an American nude and, compared to the German nudes, she was very alluring and had her pubic hair smudged to obscure the reader's view. Ibid., 95 (1933), 664. Chinese nudes were rarely featured, but two examples were "Woman Hero," in ibid., 100 (1933), 974, and "Soft Breast," in ibid., 68 (1932), 841. The only exception I could find to the disappearance of nudity after 1934 was in 1937, where an article on the suffering experienced by female models depicted a full back view of a naked nonChinese woman. The article explained that models were subjected to humiliations before they secured employment and their lives were harder than even the women "who sold their bodies." Humiliations included being interrogated on personal matters such as virginity or illnesses, as well as being examined minutely while naked for excessive wrinkles or scars. Xiu Ying, "Mote'er de tongku shenghuo" [The hard lives of models], in ibid., 283 (1937), 1276, 1278. Wang noted that the depiction of nudes "sanctioned the voyeuristic display of the female form," but it is crucial to note that Europeans made up the vast majority of the nudes and Americans the vast majority of the semi-clad sexualized beauties. Wang, "Making 'Opposite-sex love' in Print," 249. 
Similarly, actresses with bedroom eyes or aggressively direct gazes, rather than explicit sexuality, gradually replaced the sultry American starlets who dominated the back-to-front section between 1931 and 1934. The utility of the pictorial image of the American "immoral extreme" in selling copy and titillating readers diminished, tempered by the censorship regime that took upon itself the task of protecting the nation's readers from spiritual degeneration. Still, the contrast with China's own "moderate modern" women continued to operate through comparisons with an even more modest depiction of the Chinese feminine form. The boundary-stretching practices of the magazine, even with its more conservative turn, were still considerable. Hsiao-pei Yen has argued that Linglong reflected the modern woman's resistance to the New Life Movement's "regulation of her body."

\section{Glamour and modesty: What to wear? How much skin to show?}

Clothing choice stood as a clear marker of the moderation of China's fashionable modern women in the 1930s. Antonia Finnane has remarked: "In the 1930s, clearly, China was a place where women could be categorized as modern or not modern, and clothing was a major signifier of the position a woman occupied on the spectrum of modernity." ${ }^{35}$ She then explained the iconic status of the qipao in this spectrum as that particular dress "acquired weighty political, social, and moral meanings." ${ }^{36}$ Linglong showed that the qipao was not the only dress a modern woman could wear, especially if she sought to indicate her moderate version of modernity. Equally, states of undress became important markers of Chinese-ness along the spectrum of modernity in which Chinese consumers positioned themselves in a global, not just national, frame. In the illustrations and photographs decorating Linglong's pages, the amount of skin exposed and its location on the female form offered a clear vision of the moderate (modern Chinese) and the extreme (too-modern American).

34. Yen, "Body Politics, Modernity and National Salvation," 167.

35. Antonia Finnane, Changing Clothes in China: Fashion, History, Nation (New York, 2008), 5.

36. Ibid., 5. See also the contestation over the moral coding of the qipao and women's legitimate access to public space in Louise Edwards, "Dressing for Power: Scholars' Robes, School Uniforms and Military Attire in China," in Mina Roces and Louise Edwards, eds., The Politics of Dress in Asia and the Americas (Brighton, U.K., 2007), 42-64. 


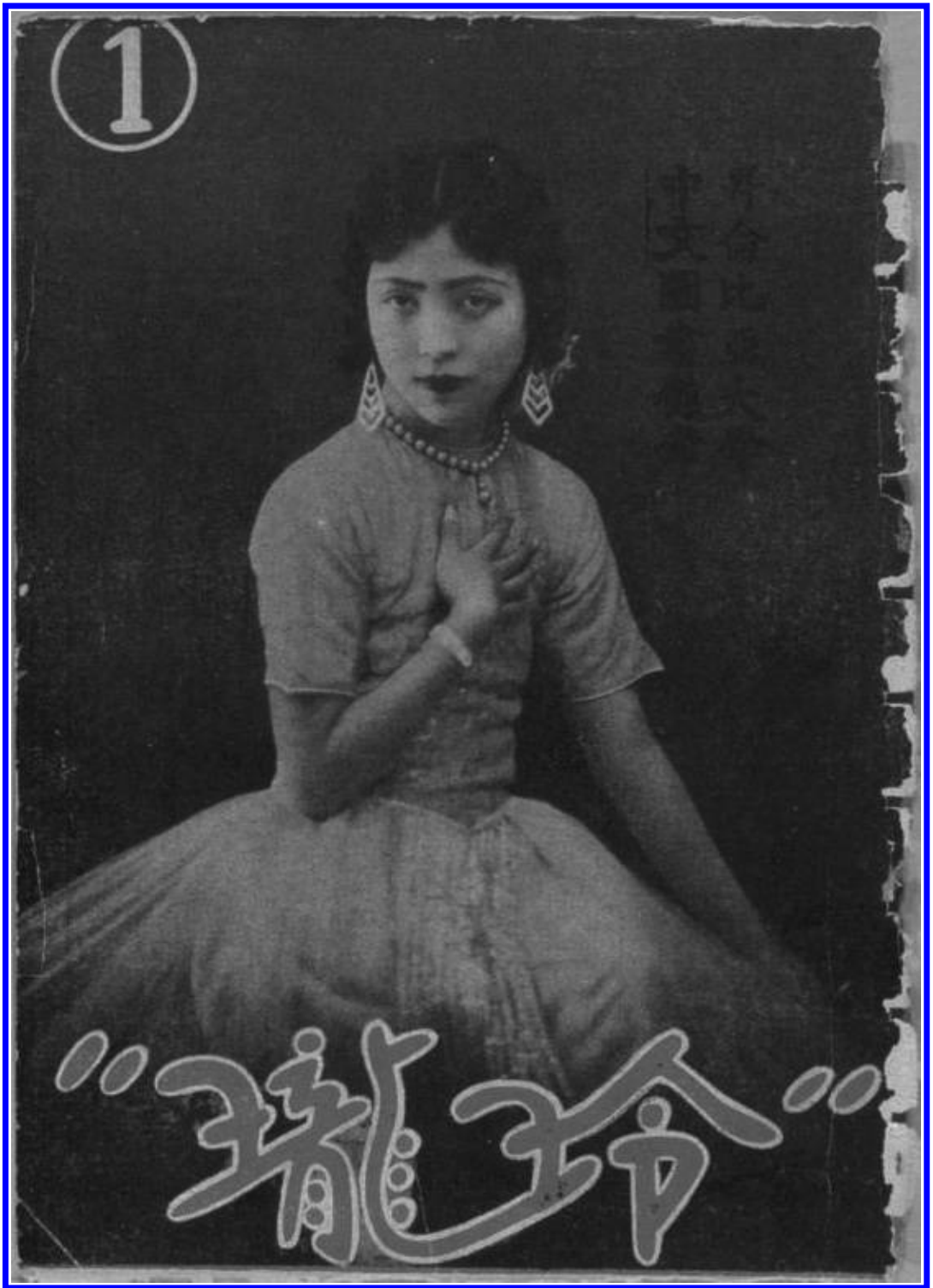

Figure 1. "Zhou Shuheng, newly married daughter of Postage Stamp King," Linglong, 1 (1931), Front Cover. Courtesy of C. V. Starr East Asian Library, Columbia University, New York. 


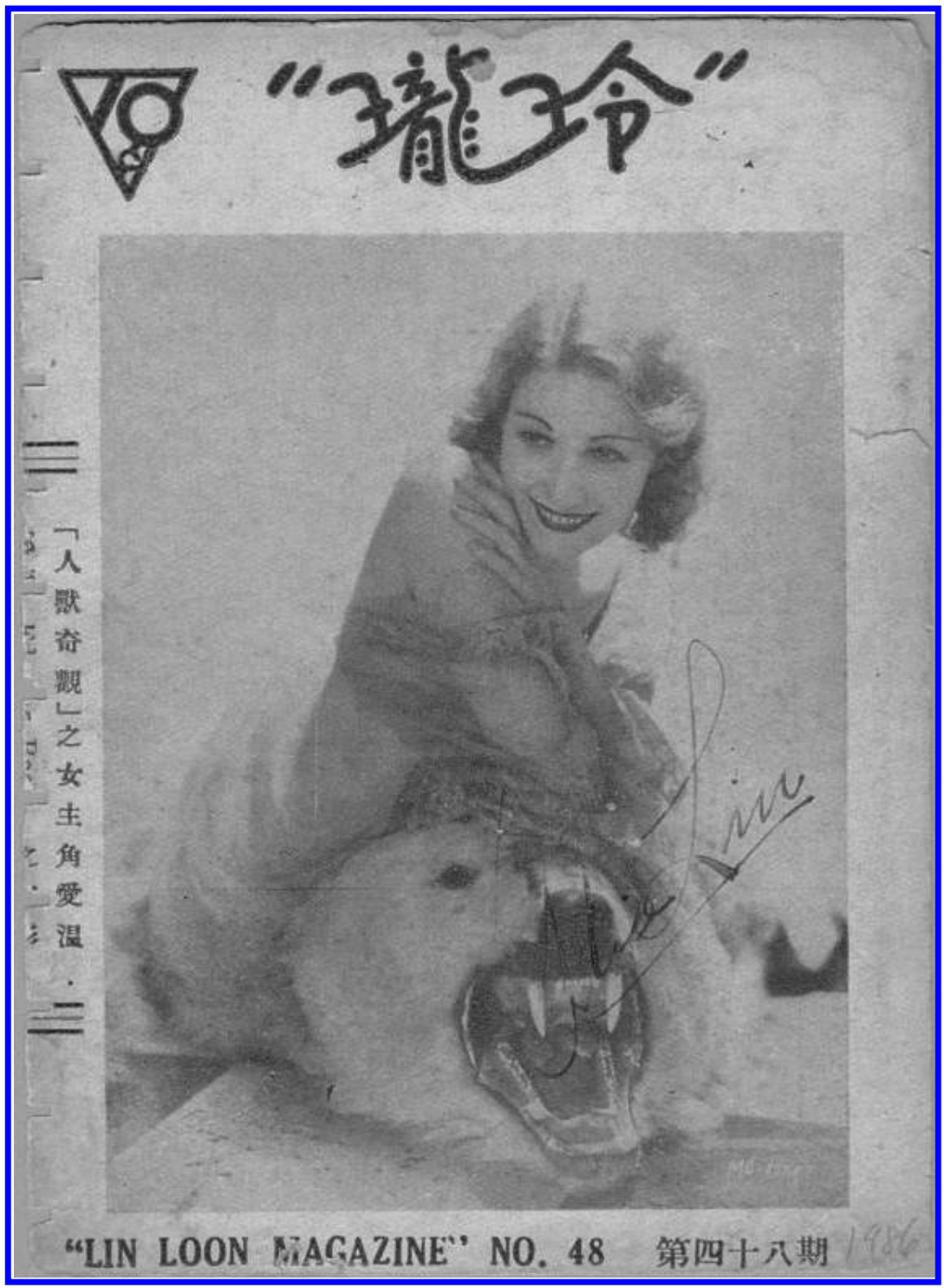

Figure 2. "The leading lady of 'Trader Horn' loves the warmth," Linglong, 48 (1932), Back Cover. Edwina Booth. Courtesy of C. V. Starr East Asian Library, Columbia University, New York. 
The magazine's Chinese women revealed limited amounts of skin, and these displays of flesh were usually limited to the extremities of their limbs. High collars neutralized naked arms, and strategically draped handbags or stockings covered legs. In contrast, American women, represented predominantly by the Hollywood movie star, appeared with bare legs, craning necks, scooped necklines, and diving backlines. The back and front covers of the first issue provide a classic example of the contrast presented to readers. The front-to-back cover shows the newly married Zhou Shuheng, daughter of postage stamp magnate, Zhou Jinjue, holding her hand modestly across her chest. She appears in hybrid-style clothing, wearing a dress that is nipped in at the waist, spreading out in European ball-gown fashion, yet the top sustains a high Tang collar that covers all of her neck and throat. The only flesh revealed is on her bare arms that stretch from her short-sleeved dress top. Her modern credentials would have been clear to the 1930s reader-the crimped and bobbed hairstyle and the nippedin waist are markedly cosmopolitan, but the high collar and modestly positioned hand signify her dignity. This vision of feminine modesty stood in stark contrast if readers started reading from the back-to-front cover. The back cover shows Hollywood movie stars Clive Brook and Evelyn Brent lying prone in a near kiss, with Brent's bare throat and upper arms occupying center frame. Edwina Booth, star of the documentary movie Trader Horn, was featured on the back cover of a 1932 issue, stretching across a polar bear skin rug, bare shouldered and draped in a diaphanous cloth. The Chinese title for the movie is "Spectacle of man and beast" (Ren shou qi guan). In the contrast between the dress style of an American movie star and a Chinese woman, readers could be reassured of the modesty of Chinese women while simultaneously appreciating their modern global fashionability.

The juxtaposition of alluring American actresses wearing clothes that hinted at the prospect of sex and the demure Chinese woman with her collared neckline and covered arms was standard throughout the life of the journal. The stories accompanying some of the pictures confirm the sexuality of the skin that Americans revealed. In Linglong's second issue, readers were treated to an article on Clara Bow, "the It girl" of 1931. The semiclad Clara gazes directly at readers with sultry bedroom eyes in a full-length picture captioned "She's so hot her clothes come off." 
The text accompanying the picture explains that the film star was not happy about being considered hot because "she knows that the hotness of the female sex can wreck all the world's grand enterprises"- a warning with deep resonances in Chinese history. Ms. Bow told readers that the labels of "hot" and "it" were hateful (naohen) and hard to take (nanshou) because it was as if "I conduct myself like the Japanese under a volcano." ${ }^{37}$ The disjuncture between high morals expressed in the text and the loose sexuality of the images was compounded by a second picture that showed Clara Bow sitting on a globe in underwear and high heels "enthusiastically (literally, "hotly") looking out at the men of the world."

The Chinese women depicted in this same issue included a Miss Zhou Ming, sitting modestly on a low bench looking over her shoulder at the reader, covered to the elbows and up to the chin in her white, fur-lined, spring outfit designed to enable her to "benefit from the warming weather." The text that accompanied the picture confirmed her modesty, running "A young woman's seclusion and quietude (Nüzi de youjing)." The ruffled and billowing skirt, along with her bobbed and crimped hairstyle, signified her firm location on the "modern" end of the tradition-modernity spectrum. On the opposite page, readers were treated to a new style of irregular hemline in a dress modeled by Miss Li Jinrong. The fabric was of large floral designs and invoked a "western style," but the Chinese-style collar covered her throat. Her arms were bare but crossed modestly in her lap as she clasped her purse. Her stockinged legs were placed together as the wall behind bore her weight and she gazed politely and rather expressionlessly at readers. ${ }^{38}$

In both Li Jinrong's dress and Zhou Ming's attire, readers were presented with a version of Chinese-ness that was modern

37. Cheng Jingqiu, "Kelaila Bao pa re" [Clara Bow fears the heat], Linglong, 2 (1931), 68-69. I am uncertain why the Japanese were referred to here and can only assume that it had to do with the then-commonplace Chinese disdain for the Japanese; the phrase may have been intended to indicate the latter's perceived lack of cultural refinement.

38. Francesca de Lago has alerted us to the significance of bare legs and leg crossing as a marker of modernity in China of the 1930s. Francesca de Lago, "Crossed Legs in 1930s Shanghai: How 'Modern' the Modern Woman?” East Asian History, no. 19 (2000), 103-144. Readers of Linglong in the 1930s would have perceived many of the bare-legged, cross-legged women featured as exhibiting particularly modern behavior. 

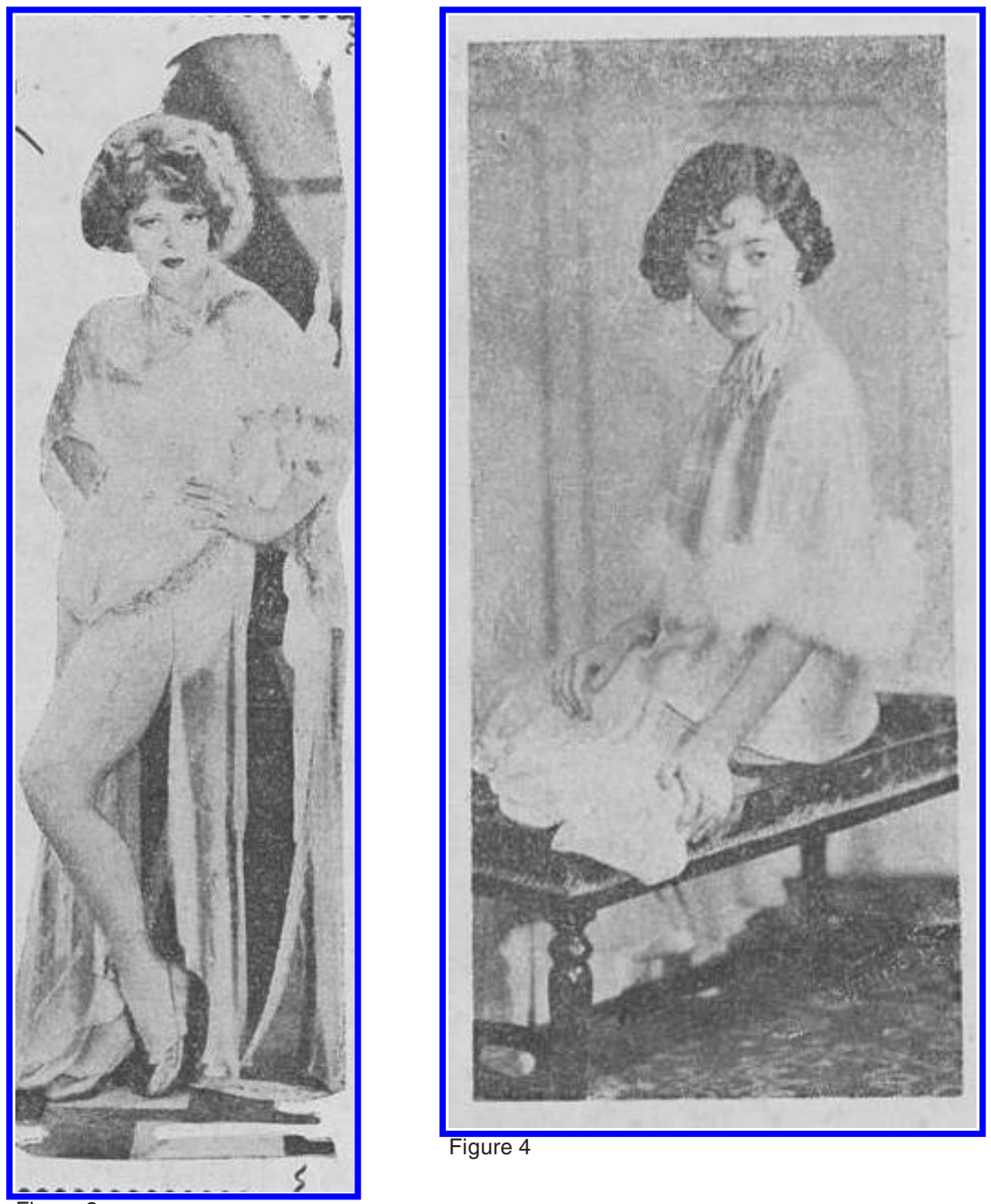

Figure 3

Figure 3. "Clara Bow: She's so hot even her clothes have come off," Linglong, 2 (1931), 68. Courtesy of C. V. Starr East Asian Library, Columbia University, New York.

Figure 4. "Miss Zhou Ming models spring fashion,” Linglong, 2 (1931), 42. Courtesy of C. V. Starr East Asian Library, Columbia University, New York. 
and global - a Chinese adaptation of western fashion. Hazel Clark argued that the spread of the qipao from the mid-1920s was a response to Chinese women's growing nationalism in which they sought a modern modesty with inspiration from the changyi-the elite Manchu women's gown-which was a much looser version of the qipao. ${ }^{39}$ The clothing modeled to Linglong's readers would appear to confirm Clark's thesis that nationalist sentiment influenced clothing choice, since the indigenization of clothing beyond the qipao also hybridized Chinese and western styles. It also confirms her point that Chinese women sought a greater degree of modesty in their styles-this normally equated to high necklines. I argue that, in order to present these new, hybrid modern Chinese styles convincingly to readers as suitable for a modest Chinese woman (while being simultaneously modern), they required an extreme of American excess as a ready comparison. The exposure of American skin and sexuality throughout the magazine facilitated this comparatively modest modernity.

The front-to-back cover of the same issue provided an even more dramatic contrast with Bow's difficulties with "hot-ness "and "it-ness." The portrait of a young beauty adorned in a laced, highnecked, intricately collared, diagonal Chinese-style dress greeted readers. Few could doubt the modesty of the image as she looks tentatively out at readers with her lips closed and head tilted down while her eyes look upward. Her modernity is marked by the crimped, bobbed hair, cut in the style of all the Hollywood starlets and stars featured, and by her status as a Hujiang University student-a very modern and privileged position for a Chinese woman in this era.

He Nan's recent study of Linglong argued that the magazine promoted a Hollywood-style beauty as the ideal feminine form, in contrast to the traditional Chinese "sickly beauty." ${ }^{40}$ But, while Linglong showed a clear departure from the sickly beauty of yesteryear, there were no pictures of Chinese women in the sultry, semi-clad glamour of the Hollywood women. Linglong was clearly setting a

39. Hazel Clark, "The Cheung Sam: Issues of Fashion and Cultural Identity," in Valerie Steele and John S. Major, eds., China Chic: East Meets West (New Haven, Conn., 1999), 155-166.

40. He Nan, "Linglong zazhi zhong de 30 niandai dushi nüxing shenghuo [Urban women life in 1930s from Linglong magazine (sic)]" (Ph.D. dissertation, Jinlin University, 2010). 


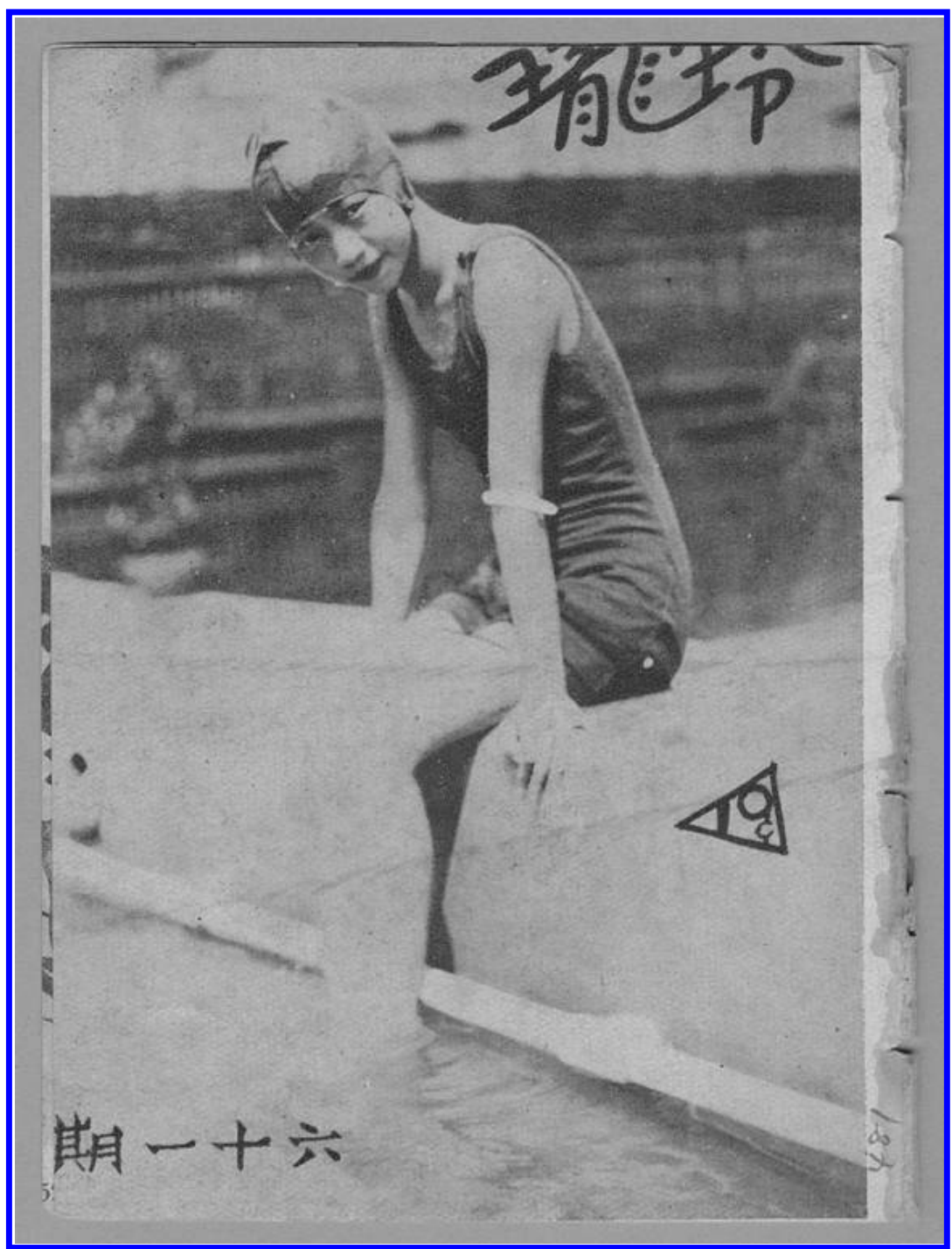

Figure 5. "Swimmer on pool's edge," Linglong, 61 (1932), Front Cover. Courtesy of C. V. Starr East Asian Library, Columbia University, New York. 


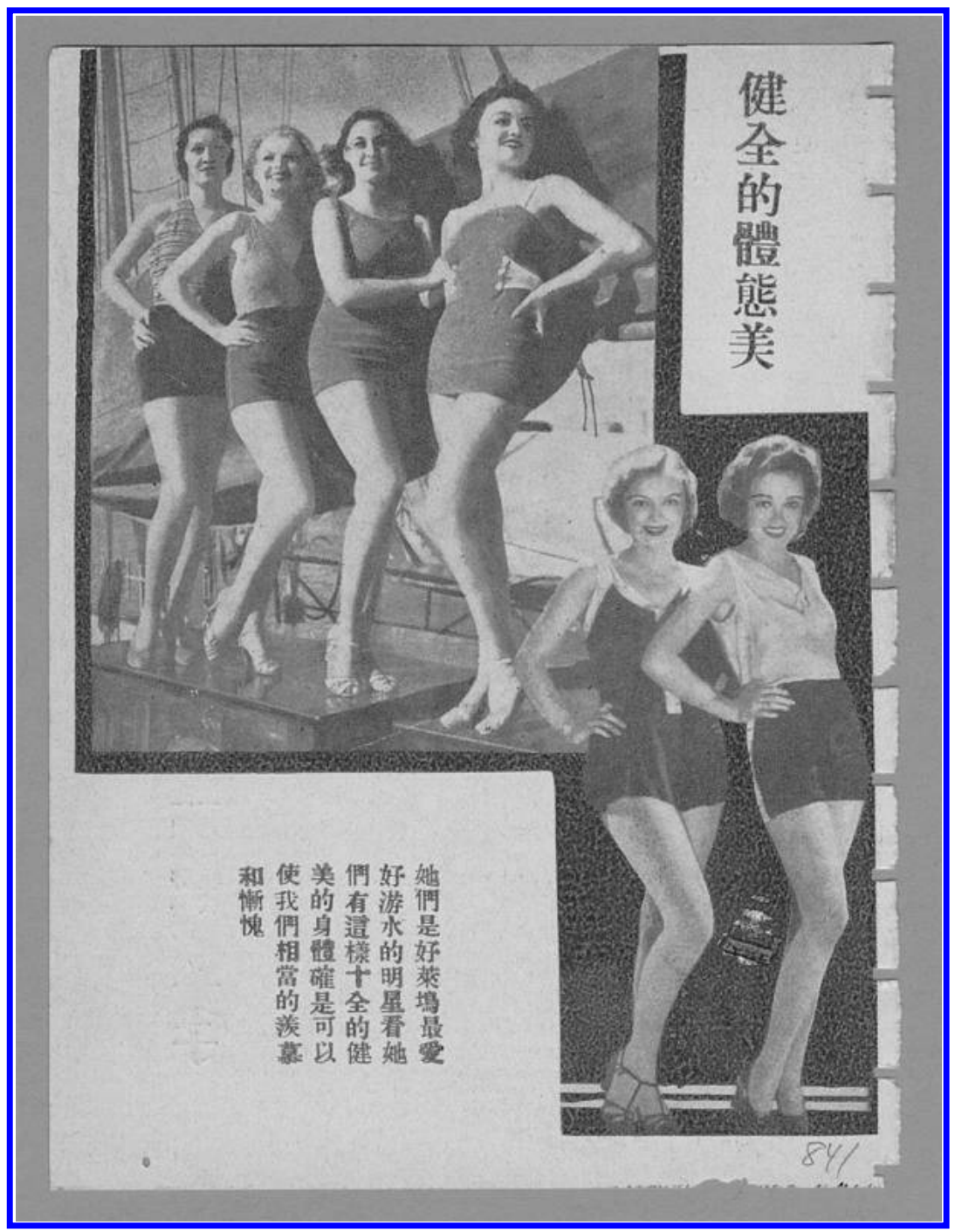

Figure 6. "Perfectly shaped beauties," Linglong, 98 (1933), 841. Courtesy of C. V. Starr East Asian Library, Columbia University, New York. 
limit on the extent to which good Chinese women should emulate the Hollywood-style of beauty.

There was, however, one important venue in which more Chinese flesh was exposed as the magazine evolved through the censorships regime-the swimming pool. At the very beginning of Linglong's life in March 1931, very little Chinese skin was revealed, but, starting in the summer of 1932, women in bathing suits adorned an increasing number of issues. By the end of the journal's life, Chinese swimmers appeared in almost every issue and sometimes with multiple pictures in a single issue. Yunxiang Gao has explained this trend as part of Linglong's engagement with the New Life Movement through its campaign to build the health and physical fitness of the nation's womenfolk and to establish the desire for a "robust beauty" (jianmei) among Chinese women. Hsiao-Pei Yen has shown that the New Life Movement's enthusiasm for a strong and fit female population enabled Linglong to counter many of the restrictions on the "nationalized" female body that the movement advocated ${ }^{41}$ The photographs of these swimming women never show languid or alluring poses-these are simply shots of young women at pool-side keeping fit and aspiring to become the much-promoted "healthy beauty." The donning of a swimming cap appears to assure readers and censors of the good purpose for revealing Chinese women's skin. Swimming caps too signified China's moderation in matters of female modernity.

In contrast, the magazine depicted American women's motivation for wearing swimming togs as their desire to look sexy. The photos never showed these women wearing swimming caps; in fact, the women frequently appeared to take to the water or pool in high-heel shoes, even when the caption implied they were models of the healthy body. They routinely modeled the latest fashions, rather than covering laps for physical health. The American swimsuit wearer was thus a sexualized form, whereas her Chinese counterpart maintained a putative modesty through the active sporting context in which she was framed. This framing does not mean she was not read in a titillating manner but, in contrast to the American woman, the Chinese one clearly had a higher purpose.

41. Yen, "Body Politics, Modernity and National Salvation," 182. 
Clothing choice and the extent and context of revealed skin served as key sites upon which Linglong could map the boundaries of appropriate Chinese modernity for readers. Although the Chinese women depicted were frequently breaking new ground in terms of modesty, compared to their mother's and grandmother's generations, they were nonetheless framed as relatively moderate by the depiction of excessive American flesh, excessive sensuality, and excessive modernity.

\section{What company should a moral, modern woman keep?}

As China moved into the twentieth century, long-held ideals about "good girls from good families" remaining secluded from the public sphere and segregated from non-family men were fading. Men and women agents for change sought to find legitimate locations in which members of the opposite sex could be seen together without irreparably damaging the young woman's reputation. The advent of girls' schools provided a legitimate reason for good girls to be seen in public, and the eventual move to coeducational environments confirmed the idea that advancing one's education in a modern environment was sufficient reason for deviating from old patterns. The expansion of factory work and white-collar clerical work in Shanghai and other coastal cities contributed to this trend of increased public intercourse between men and women through the first decades of the century. By the 1930s women from all walks of life were moving around Shanghai independent of men or female chaperones for work, recreation, personal cultivation, and education. They sought leisure in the city's many dancehalls, movie theaters, and coffee shops, but they needed to know how much public mingling with the opposite sex was too much. Again, America provided the extreme case within which Shanghai's young women could come to recognize their own moderation and modern morality.

Linglong's editor Lin Zemin directly targeted the perceived dangers of unfettered intermingling-especially the loss of sexual chastity-in the first two issues. Titled "The Mirror for the Modern Girl," the article explained that "99 percent of western girls are no longer virgins" because, although these countries claimed to have attained culture and wealth, they lacked propriety (lijiao). According to Lin, western women had an extreme predilection 
for social intercourse ( $k u$ shi she jiao) and spent too much time in movie theaters and dancehalls mixing with men. The main article was accompanied by an inset piece with a line drawing of a man and woman kissing on a park bench (her garters and thighs exposed) with the English words "Keep off the Grass" on a placard behind. Another item on the same page was a two-page banner photograph depicting a line of more than twenty western women in swimsuits at a beach, leaning forward on one leg, with the other leg stretched to the sky. It bore the caption "Long-legged beauties dancing wildly on the beach" (the literal translation is "crazy dancing of the beach perfumed legs"). ${ }^{42}$ The second part of Lin's article in the subsequent issue narrowed the focus from a generic "western" to the specific American context. Lin reminded readers that "the bulk of women have lost their virginity" (shi shen-literally "lost their bodies") in these depraved countries and then outlined recent developments in the United States aiming to mitigate this excess. Readers learned that the late Albert E. Pillsbury (18491930) gave $£ 20,000$ to four universities (Harvard, Yale, Columbia, and Princeton) for a program aimed at "prohibiting women from going out" (jinzhi nüzi chumen).$^{43}$ Lin reported that, although the four universities had yet to formally accept the money, the donation showed that leading Americans were also contemplating the rights and wrongs of objectionable customs (e su) and were aware of the dangers of good women going out too frequently. Lin then framed the problem for the "young women of my country" as being one of how to reach beyond the boundaries of the old customs while avoiding the evil customs of extravagance from the West (xifang zhi shechi e su) ${ }^{44}$ The article was accompanied by a picture of Chinese schoolgirls playing volleyball for a public audience. This juxtaposition provided readers with a context for appreciating the "reasonable" scope for women to go out into public spaces with the "unreasonable" western extravagance.

42. "Haitan xiangtui zhi kuangwu" [Long-legged beauties dancing wildly on the beach]. Lin Zemin, "Modeng nüzi de mingjing" [Mirror for the modern girl], Linglong, 1 (1931), 18.

43. It is unclear how the purported money was meant to achieve these aims since none of these universities had women students at this time.

44. A donation of this kind from Albert Pillsbury, a man who was supportive of women and African Americans, is rather perplexing. Lin Zemin, "Modeng nüzi de mingjing," 55. 
This mixed message was typical of Linglong's approach to managing narratives about the correct (moderate but modern) balance on significant social reforms. The editors set themselves apart from those crusty old traditionalists, who would keep their daughters and wives secluded in order to demonstrate their womenfolk's modesty and their families' virtue, by showing healthy, modern, and athletic women improving their minds and bodies in the public sphere. At the same time, they distanced themselves from the rampant public socializing that that was allegedly the scourge of American society by presenting an exaggerated and partial view of the situation in the United States. Linglong's readers, if they followed the editors' advice, would be able to chart a course between these two extremes and create a new vision of Chinese modernity with just enough modesty and virtue and just enough freedom of movement and social intercourse to be both modern and Chinese.

Frequent articles on balls and dance events consolidated the message that China's modern women could be confident about their ability to forge a new modern sense of womanhood without completely losing their sexual virtue. For example, Miss Bei La, a writer from a women's college, wrote an article on a recent Charity Ball and reported how Madam Shi, having danced herself crazy (kuang $w u$ ) half the night, rejected praise of her dancing skills, saying that it was due to her dance partner, "Mr. W." Bei La commented that "Whenever a woman dances well she always gives all the credit to her "partner." Marking the cosmopolitan nature of the activity, both "partner" and "Mr. W." were written in English. Madam Tang and her niece from Ningbo also enjoyed the night, chatting in a lively fashion in their native Ningbo-ese throughout the evening. The happy event was marred only by the loss of a pair of expensive embroidered dance shoes at the end of the evening. ${ }^{45}$ Readers learned that modern Chinese women could dance with men, have fun, enjoy themselves, be glamorous and cosmopolitan, and still be sufficiently modest to maintain their dignity. Madam Shi's dancing abilities were dependent on her partner's talents, rather than her own frequent attendance at dancehalls. The intergenerational familial context of niece and aunt attending together

45. Bei La, "Cishan tiaowuhui de zhenwen" [Tidbits from a charity ball], Linglong, 1 (1931), 7. 
provided reassurance about the legitimacy of "going out" and its containment by family oversight.

Finding the correct amount of socializing required women to develop new skills that would protect them against common dangers they might encounter in interacting with men-men were generally revealed as an untrustworthy sex in Linglong's pages. ${ }^{46}$ Liang Peiqin provided readers with help in determining the appropriate limits of behavior and the best defenses against men's trickery. In an essay titled "My Boundaries," Miss Liang explained that the movement of young women from their households into society was definitely "not a bad thing." By moving in society, they could learn about the hypocrisy of men and protect themselves from falling prey to their trickery. She opined that young women schooled only in the old rules of feminine propriety were easy prey to men's tricks. The lives of the girls of yesteryear were "too dull and dry" (kuzao). But now, she advised, it was not a "free for all." Modern Chinese women did have restraints: "[W]e cannot go too far, if we go too far then we will suffer censure; and if we are too backward then people will laugh at us." She noted that young women always had to act according to what would suit other people. But, as all the readers would have known, the reason that young women wanted to go out into society was to make more male friends (nanyou).

A young woman needed to guard against a number of hazards. She should not remain silent in the presence of her male friend but should give him the feeling that she was a good companion. At the same time, she had to maintain a certain "coldness of heart and sharpness of eye," so that she could accurately assess the actions of the opposite number. "Does he have ill intent or not?" If he did, then the young woman should immediately break off all contact with him. Second, Liang advised her readers, young women should be very careful not to "fall in love at first sight" or think "all men are wonderful." ${ }^{\prime 7}$ To reinforce the validity of her advice about "limits," Miss Liang included a picture of herself in very modest Chinese attire with her head slanted shyly to one side and her hands protectively crossing her chest.

An equally modest Miss Zheng Meixiu gave female readers advice on dancing and, like Miss Liang, contrasted contemporary

46. Mittler's "In spite of gentility" explores Linglong's negative appraisal of men.

47. Liang Peiqin, "Wo de jiaoji" [My boundaries], Linglong, 1 (1931), 10-11. 
women with those from "the bad old days." She presented the women of China's past as secluded in their family homes, separated from the world, and deprived of social intercourse and entertainment. She continued by noting that most people now recognized that the participation of today's women in public activities had brought benefits not only to women but also to society more broadly. Still, when it came to the question of dancing, people with traditional values argued that dancing diminished or even destroyed feminine dignity. These views were simply too extreme, according to Zheng. She advised her readers that just because some women danced in a manner that had no limits (wu xianzhi) or danced without any rules (bu an guiju), one should not dismiss all dancing as inherently harmful. "I love dancing, but I make sure that my dancing joy (wu xing) should not exceed my rules (guiding) so that I reap the benefits for my body and mind of the exercise derived therein." ${ }^{\prime 4}$

Other articles throughout the magazine adopted a similar logic. The bad old days were too restrictive, but moralists fearing the decline of social values should be reassured; just because women had greater freedom now, this freedom was not completely devoid of limits. Linglong's modernity was framed around the principle of moderation and pitched neatly between the poles of Confucian confinement and American depravity caused by the lack of limits, rules, or even guidelines. ${ }^{49}$ The pairing of the comparatively radical content of the written text (e.g., young women from good homes could and should dance and socialize with men in public) with modest pictures of the authors served to reinforce the core principle that Linglong readers needed their own carefully considered limits.

Modern women would also encounter men in the workplace, so in 1934 Linglong provided a ten-point list of invaluable information for appropriate workplace behavior as related to establishing the boundaries of one's personal and professional lives. Women should avoid talking about their love lives to colleagues because public discussion of private matters could lead to malicious gossip.

48. Zheng Meixiu, "Nüzi yu tiaowu" [Women and dancing], in ibid., 15.

49. One issue of the magazine treated readers to the "extremism" of American women's public life with a picture of nine women bank employees, of a wide variety of ages, pointing handguns directly toward the readers as they practiced skills for retaliating against bank robbers. "Meiguo yinhang nüshiyuan" [Women workers in an American bank], in ibid., 221 (1936), 192-193. 
Readers were also cautioned against chatting and laughing with male colleagues since this was disrespectful of the workplace. Likewise, one should never use the work phone to talk to one's boyfriend or to talk about romantic matters, lest it invite the disfavor of one's manager. ${ }^{50}$

Prepared with the knowledge that 99 percent of American girls had lost their virginity, according to the magazine's very first issue, Linglong's readers could proceed through subsequent years of reading observing just how America had sunk to its current state of depravity. Excessive sexual desire had to take a lot of the blame for the moral decay. Images of American movie stars hugging, kissing, or nearly kissing men appeared frequently up to 1934. For example, in issue 97, Sally Eiler and James Dunn sat embracing in an affectionate pose. In issue 99, Marlene Dietrich and Clive Brook were featured in a close embrace in a promotion photo for the 1932 movie Shanghai Express. Helen Hayes and Ronald Colman were locked in a desperate near kiss in the back-to-front cover of issue 100 of 1933, as were Gary Cooper and Tallulah Bankhead in the back-to-front cover of issue 101 in the same year. The kissing fest ceased after 1934 as the censorship provisions began to limit explicitly sexual images. Significantly, throughout its entire publication run, Linglong never included a picture of a Chinese woman kissing or being kissed, and it rarely showed them embracing or being embraced. ${ }^{51}$ Overwhelmingly, the magazine presented images of Chinese women socializing with other Chinese womenpictures of mixed-sex gatherings were extremely rare, even though the articles themselves devoted considerable textual space to the discussion of socializing with men.

50. Wu Lijuan, "Shiye funü shijie" [The world of working women], in ibid., 127 (1934), 74-75.

51. The first issue promised a more daring approach with a small photo of Chinese actress $\mathrm{Hu}$ Die and her then boyfriend and one-time fiancé, Lin Xuehuai, an actor whom she had met on site when making Deserted Fan in Autumn (Qiushan yuan, 1925). They had been engaged, but the relationship broke off amid much scandal and rumor. The picture of the couple shows her in high-necked Chinese clothing with him standing behind, his hand on her shoulder protectively, in a western suit. Linglong, 1 (1931), 27. In 1933 readers were treated to some pictures of Chinese couples hugging in ibid., 91 (1933), 424, but these too were movie stars acting their romance. In contrast, Americans were expert kissers. See the story about Mexican American Hollywood "sex symbol," Ramón Novarro, who was described as having a "Ph.D. in Kissing," in ibid., 5 (1931), 172. The article includes the comment "We should respect his experience." 
The absence of images does not mean that readers were left devoid of advice about the politics of moderate kissing for a modern and respectable Chinese woman. But, as the article titled "America's kissing competition" of 1934 declared, "there is a competitive trophy for everything in America." The article related that a young woman and her boyfriend won the competition by sustaining their kiss for three hours and two minutes: "[T]he strangeness (hao xinqi) of Americans is clear to see from this [event]." ${ }^{25}$ In contrast, Chinese couples would kiss in moderation. Miss Shi Baoqin, author of a book titled A Young Woman's Love Life (Nüzi lian'ai shenghuo), tackled the matter of kissing directly in a column for Linglong. She explained that, while she understood many young women regarded kissing "as a shameless and seedy business which they would seek to distance themselves from, they are quite wrong." In fact, our expert reminded readers that kissing was an expression of a man's love for a woman, and if she was kissed, that woman should kiss back. If she simply received a kiss and "pretends to act like a dullard, half resisting and half relenting" (jia chi jia dai, ban tui ban jiu), then it just showed that women were no use. ${ }^{53}$ Kissing per se was not a problem-a moderate amount of kissing was appropriate for the modern Chinese woman. But public displays of lustful kissing were presented as being the preserve of the Hollywood star and her beau.

\section{Preventing the revolving door of marriages and divorces}

The consequences of the American enthusiasm for embracing was made clear to readers in editorials that noted the fragility and fluidity of the American woman's relations with men. Throughout the magazine's life, readers were treated to tales of the romantic lives of American movie stars and then their inevitable divorces. The first issue, for example, included a story titled "Janet Gaynor After Divorce," which featured an interview with Gaynor, held in a San Francisco dancehall, about her emotional problems (ganqing wenti) with her husband, Jessie Lydell Peck. Gaynor explained to readers that she was just a pitiful and weak woman who was trying

52. "Meiguo zhi jiewen bisai" [America's kissing competition], in ibid., 126 (1934), 86.

53. Shi Baoqin, "Wo duiyu jiewen biaoshi" [My opinion on kissing], in ibid., 3 (1931), 76-77. 
to reduce the hassles in her life by swearing never to marry again or even get close to anyone again. From that point forward, she would just live off her own efforts. A picture of the couple playfully embracing in happier times accompanied the article. ${ }^{54}$ Later issues included discussions about the fickle Gaynor's new romance.

The excess of freedom in America led to a revolving door of romance and separation in a world apparently devoid of moral concerns for either the woman or man, and certainly no anxiety about preserving marriages on the part of American women. In contrast, Chinese women received a list of their responsibilities in order to prevent husbands from wandering. Miss Zhang Pinhui provided a six-point list of responsibilities to ensure that husbands stayed faithful, including wearing beautiful clothing at home as a matter of course; recognizing that, when a "husband fears his wife," he is more likely to stray; being warm and affectionate when a husband comes home tired at the end of the day; managing the house smoothly and ensuring that the children are educated appropriately; going out with friends only at times when he is also out; and talking directly with him about any difficulties. These six points would ensure a happy family. ${ }^{55}$ Handy hints about how to manage children or outlines of a typical list of household duties that women must undertake frequented the pages of Linglong. ${ }^{56}$ Still, Linglong's readers were not alerted to the fact that such lists advising women on how to make a happy home were also common in the United States at this time in equivalent popular magazines. This significant aspect of American culture would have disturbed the moral schema in which the United States was the imagined extreme of freedom, where frequent marriages and divorces were commonplace and free of consequences. Instead, Linglong's readers were told, "Up to the present American women are the most richly independent and capable in the entire world (other than those in the Soviet Union). Yet, they are still unsatisfied with

54. Cheng Jingqiu, "Lihun hou de Zhenni Gainuo" [Janet Gaynor after her divorce], in ibid., 1 (1931), 33.

55. Zhang Pinhui, "Zhangfu you waiyu" [Husbands having extra-marital affairs], in ibid., 1 (1931), 4-5.

56. See, for example, Zhang Pinhui, "Nüzi jiating zhi chouhua" [A woman's household planning], in ibid., 2 (1931), 45. A modest picture of Miss Zhang accompanied this article and its text reminded readers "not to be too rigid" in household management and to adjust spending to fit the income of the "foreign affairs ministry head" (waijiaobu zhang)—one's husband. 
these conditions." A woman in Texas was described as proposing a "Wives' rights recovery bill" (qiquan fuxing fa'an). This proposed bill stipulated that husbands must take their wives out to dinner once a week; that when the husband was at home, he should take care of the children alongside his wife; that unless the household had an invalid or emergency, the husband should allow the wife to sleep in twice a week; that wives should have the right to watch two movies each week; and that neither the husband nor his friends should drink alcohol while eating their dinner. ${ }^{57}$

In contrast to the perennially "dissatisfied" American wife, Linglong's Chinese wives were restrained. Moreover, even though by today's standards Linglong was constructing a vision of a rather patriarchal family, if we situate the magazine's advice into the China of the 1930s, the views propagated were quite radical. The idea that a wife could prevent her husband from seeking pleasure outside their marriage marked a significant break from old ideals of a noble wife approving of and sometimes arranging concubines for her husband and the common occurrence of married men frequenting brothels. The conjugal unit of husband and wife, as opposed to the large multi-generational family, was gaining ground in urban China, with the new Civil Code's provisions on marriage of 1931 reflecting the new love-match ideal. ${ }^{58}$ Miss Zhang's six-point advice list to readers did not include "getting on with his mother" or "serving his parents"-both significant departures that readers would have noted as identifying the progressive and very modern models of marriage presented in the magazine. Linglong established a context in which the preservation of new-style modern marriages was a good thing for China and Chinese families. This new style of stable, companionate marriage was contrasted simultaneously with the frivolous attitude that American women adopted with regard to marriage and the restrictive old-fashioned arranged marriages of the Chinese past.

To achieve this ideal marriage, one needed a good husband. Miss Yang Xiujuan advised her readers about how to choose an ideal husband and explicitly warned against choosing on the basis

57. (Liu), "Meiguo zhi qiquan fuxing yundong" [The movement to recover wives' rights in America], in ibid., 134 (1934), 533.

58. Linglong kept its readers abreast of their new legal rights in a special column on Legal Matters. See ibid., 89 (1933), 303-302 where women were taught about their rights in marriage and in inheritance. 
of his wealth. She declared that, although she herself was not married, she had observed many marriages and come to the considered opinion that marrying for money was a recipe for marital misery. Instead, she recommended choosing a husband who was "equivalent to your position." ${ }^{\text {99 }}$ Her detailed discussion of the nature of this "position" explained that women should select men who had equivalent education, similar ideas about personal conduct, and equivalence in abilities, family finances, temperament, and age. The rationality of her recommendations for marital happiness was then confirmed in her final paragraph when she drew a comparison to an American survey. According to this survey, 20 percent of American women chose a husband based on his health, 19 percent on wealth, only 8 percent on education, and a paltry 6 percent on personal conduct. What further evidence did a modern Shanghai woman need? Americans' supposedly flippant attitude toward marriage was reflected in their flippant attitude toward partner choice-wealth and health dominated the marriage market in the land of the "too free." The modern Shanghai woman, equipped with her own educational assets and armed with a sense of her own power of choice, ideas about her own personality type, and individual preferences about personal conduct, would be able to make a modern marriage, if she so chose, on her own terms. In so doing, she could avoid the twin traps of staying in a miserable marriage, as had her mother and grandmother, or swinging wildly from marriage to marriage, partner to partner, as Americans were imagined to be prone to do.

Avoiding marriage altogether was another theme common in Linglong's annals. The reasons were clear: Men were too fickle in their affections and marriage was likely to bring work and bother, whereas a young woman could study a bit longer or secure her independence and avoid marriage altogether. ${ }^{60}$ In 1944 fiction writer and celebrity Shanghai resident Eileen Chang wryly described the typical Linglong reader as being torn between dating and marriage:

On the one hand, Ling long imparted the beauty secrets of movie stars, and on the other hand instructed "beautified" and "made up" girls how to keep close guard against the attacks of men, because all men harbor

59. Yang Xiujuan, "Wo de zhangfu guan" [My view on husbands], in ibid., 3 (1931), 82-83.

60. Yang Yizhu, "Bu jia zhuyi" [Against marriage-ism], in ibid., 1 (1931), 12-13. 
bad intentions. True dating is dangerous, but marriage is even more dangerous, because marriage is the tomb of dating. ${ }^{61}$

Alternatively, Liang Peiqin recommended living apart from one's husband after marriage so that a woman's freedom could be maintained and the couple would be able to respect each other's independence. ${ }^{62}$ The modern marriage was better than the traditional marriage, but readers were invited to consider even more radical options as well in the formulation of a modern form of independent womanhood. Frequent marrying and divorcing was not one of these options - it was an American extreme.

The American enthusiasm for divorce was a repeated feature of the magazine. For example, in 1933 readers were treated to one of the many "only in America" stories that filled Linglong's pages, in which a woman divorced her husband after discovering his adultery. The husband had bought his wife a new dress that he proudly declared was "one of a kind." The proud wife was perplexed when she found another woman wearing the same dress. Confronting her husband, she soon discovered that he had lent her dress to his lover. Suing for divorce was the American woman's immediate solution to this humiliation. ${ }^{63}$ But the way divorces were conducted was also depicted as being immoderate and excessive. In 1934 Linglong related a tale of the divorce laws in Chicago, which allowed a divorced wife to receive alimony from her ex-husband even after he died-even death failed to curtail America's presumed divorce extremism in this vignette. ${ }^{64}$ That same year another article titled "American Divorce Statistics" reminded readers that Americans led the world in the number of divorces and that divorce was not a complex legal process at all. Americans apparently regarded getting married and divorced as easily as "we go to a restaurant for a meal." ${ }^{55}$

61. Chang, "Talking About Women."

62. Liang Peiqin, "Xiwang nanzi fen ju" [Hoping to live apart from men], in ibid., 3 (1931), 86.

63. "Yixi yishang lihun tiaojian" [A set of clothes as a factor for divorce], in ibid., 88 (1933), 373. A 1937 example of the view that Americans were flippant about marriage, which was literally tagged with the phrase "in America where there are so many strange things," told of a woman who put her husband up for sale. "Chu mai zhangfu" [Selling off a husband], in ibid., 283 (1937), 1223-1224.

64. "Guanyu lihun shanyang fei" [On divorce alimony], in ibid., 130 (1934), 306.

65. "Meiguo lihun de tongji" [American divorce statistics], in ibid., 148 (1934), 1457. 


\section{Conclusion}

Linglong magazine viewed its role in helping China's modern women understand how to manage their lives, manage their relationships, and manage their fashion in a very serious manner. Recognizing that the old methods were no longer relevant, Linglong provided a regular commentary on how to be modern and how to be Chinese at the same time. International comparison was fundamental in this project of creating a modern path for China, and the nation that featured most prominently in all comparisonsexplicitly and implicitly_was the United States. In 1933 Linglong's readers were presented with a serialized survey comparing women around the world. The list of ten countries covered started with the United States (number 1) and ended with China (number 10). There was no sense that the countries were ranked upon any particular criteria, but the framing of the list by the United States and China suggested the weight of readers' interest lay with these two nations. The United States was regarded as having women who placed particular emphasis on freedom and independence so that they always preferred to go out in society rather than hiding at home: "That's why America has the most professional and vocational women and has the most advanced women's rights." French women were the most pure and naïve, gentle and soft. English women were serious and hard-working, obedient to their husbands, and virtuous in their family matters. Japanese women were the most oppressed and pathetic. Chinese women were divided into two categories: the hard-working and uneducated rural women, and, perhaps in a challenge to readers, the educated urbanites who did nothing at all with their time. The future of China, the author argued, lay in merging the best attributes of both these types of Chinese women. ${ }^{66}$

Such explicit comparisons of nations were far less common than the implicit comparisons made in images and texts that established the possibility of a moderate modernity for China's Modern Women. The imagined excess of the United States and the image of "boring old China" provided the contrasting extremes within which Linglong's readers could find a modern, and relatively

66. Zhu Minwan, "Shijie geguo nüxing de bijiao-shang" [A comparison of women around the world-Part 1], in ibid., 90 (1933), 340. The second part of the article appeared in ibid., 93 (1933), 520-521. 
virtuous, path through life. Without the imagined depravity and excessive freedom of the United States, such a "moderate" path would be revealed for the radical and revolutionary shift it was in actuality. China's political leaders of the 1930s and 1940s had moved away from earlier calls for outright westernization, but they sought nonetheless to produce a modern, cosmopolitan nation that would engage with the United States on this new basis.

Linglong shows us the mechanisms by which these fundamentally radical but superficially conservative political ideals were manifesting themselves in the daily lives of China's most modern citizens. The contradictions between modernity and Chinese-ness could be resolved by the creation and circulation of an imagined American modern extreme to which China would never aspire. The imagined America was possibly more influential in effecting broad-based social change on the personal and private in 1930s China than the presence of the real Americans in Shanghai's foreign concessions. Few ordinary Shanghai people would have had intimate contact with the latter, whereas Linglong reached right into the living rooms and handbags of Shanghai's modern, aspirational women. 